\title{
Um elogio à sedução, ou a biblioteca como espaço de leitura ${ }^{i}$
}

Fabrício José Nascimento da Silveira

\begin{abstract}
Doutorando em Ciência da Informação pelo Programa de Pós-Graduação em Ciência da Informação (PPGCI/UFMG)
\end{abstract}

Partindo de uma experiência literária, o presente texto se propõe a tecer algumas considerações sobre os seguintes questionamentos: o que é a leitura e a quem podemos denominar de leitor? A biblioteca é, de fato, um espaço capaz de ampliar os recursos que dispomos, para compreender e interpelar o mundo e a realidade que nos cerca? Para tanto, adota como premissas que a leitura não se configura enquanto prática de busca e de reprodução acrítica de sentidos previamente fixados pelo produtor de uma dada obra e que todo leitor deve ser compreendido como um sujeito autônomo, que circula e se apossa livremente do texto, criando, a partir de seus anseios, habilidades cognitivas e lugar social, interpretações próprias para o signo que manipula. Signo originado e preservado pelas mais distintas esferas culturais, com especial destaque para as bibliotecas, uma vez que estas se portam como pouso seguro para todos os delírios, sonhos, paixões, aventuras e desventuras da alma humana. Razão pela qual adquirem, e é isto que se pretende defender, a capacidade de encantar, fascinar e seduzir até mesmo o mais intransigente dos usuários, tal qual o fez com o protagonista da narrativa aqui enfocada.

Palavras-chave: Biblioteca; Biblioteca - Leitura; Leitura - Prática social; Leitura - Produção de sentido; Biblioteca - Prática cultural.

\section{A compliment to seduction, or the library as a reading space}

Beginning from a literary experience, this text intends to sketch some considerations about the following issues: what is reading? Who we can denominate reader? Is the library really a space that can amplify the resources which 
are used to understand and question the reality that surround us? To achieve this goal, the article adopts as premises that reading does not take the form of practices of seeking and uncritical reproduction of meaning that are previously frozen by the producer of any work and that any reader must be understood as an autonomous subject that circulates and appropriate the text freely, creating their own interpretations for the signs that manipulate based on their wish, cognitive abilities and social places. Such signs are originated in and preserved by distinct cultural spheres, especially the libraries, since they work as a safe harbor for deliria, dreams, passions, adventures and misfortunes of human soul. That is the reason why libraries acquire (as we wish to assert in the text) the capacity to enchant, fascinate and seduce even the most uncompromising user, as the protagonist of the narrative that is brought to the attention here did.

Keywords: Library; Library - Reading; Library - Social practice; Library - Meaning production; Library - Cultural practice.

\section{Introdução}

A palavra associa o traço visível à coisa invisível, à coisa ausente, à coisa desejada ou temida, como uma frágil passarela improvisada sobre o abismo (CALVINO, 2008, p. 90).

Em um de seus vários momentos de intensa criação literária, Ítalo Calvino nos apresenta um personagem emblemático, cujos feitos narrados acabam por se converter em valioso referencial simbólico para todos aqueles que buscam lançar um rastro de compreensão acerca dos gestos e fazeres que atravessam o universo da leitura, bem como dos processos que definem as bibliotecas como lócus privilegiado para que a alquimia de tal prática se desenvolva e se efetive.

Fedina, general respeitado nas terras da Panduria, em uma fria manhã de inverno, se vê encarregado pelo Estado-maior de seu país da seguinte missão: reunir o exército panduriano e marchar em direção ao velho palácio, que abrigava a maior e mais antiga biblioteca da região, para avaliar, por meio de cuidadosa leitura, se os livros, ali preservados, continham opiniões contrárias ao prestígio militar.

Desta feita, ao chegar à biblioteca em um dia qualquer de novembro, Fedina decretou a imediata paralisação das atividades que nela se exerciam, trancou suas portas seculares e expulsou todos aqueles que ali trabalhavam. Além disso, arregimentou sentinelas em suas vias de acesso, onde foram afixados cartazes, proibindo a entrada de usuários, por causa das grandes manobras que ali se dariam, até que as mesmas fossem concluídas. Por não ser versado em matéria bibliográfica, solicitou 
que do pessoal da biblioteca ficasse apenas um velhinho, o senhor Crispino, recrutado para explicar aos oficiais o lugar dos livros.

Com os padrões logísticos engendrados, decidiu-se que "o general controlaria a classificação dos volumes e aplicaria carimbos diversos, dependendo se o livro fosse declarado para ser lido por oficiais e suboficiais da tropa, ou fosse denunciado ao Tribunal Militar" (CALVINO, 2001, p. 75). Seguindo-se, metodicamente, tal recomendação, ao fim de cada dia de trabalho, se produziria um relatório a ser transmitido, via rádio, ao comando supremo, cujo teor deveria dar conta do total de volumes examinados, do número de exemplares retidos e quais deles eram declarados adequados à leitura pública.

No entanto, após semanas de intensa leitura, algo começou a modificar tal rotina: "no comunicado vespertino da comissão, o número dos livros examinados era cada vez maior, mas já não se relatava nenhum dado sobre veredictos positivos ou negativos. Os carimbos do general Fedina iam ficando ociosos" (CALVINO, 2001, p. 77). Além disso, "a floresta dos livros, em vez de ser desbastada, parecia ficar cada vez mais emaranhada e insidiosa". (CALVINO, 2001, p. 76). Sendo assim, sobre o prosseguimento dos trabalhos da comissão, não se conhecem muitos detalhes: o que aconteceu na biblioteca, nestes longos meses de inverno, não foi descrito, "mas o fato é que os boletins radiofônicos do general Fedina passaram a chegar cada vez mais raramente ao Estado-maior da Panduria, até que pararam de vez" (CALVINO, 2001, p. 77-78).

Aterrorizado pelo silêncio, o comando supremo decretou que o general concluísse sua investigação o quanto antes, devendo este apresentar um exaustivo relatório de seus feitos.

A ordem chegou à biblioteca quando o espírito de Fedina e de seus homens se debatia entre sentimentos opostos: por um lado, estavam descobrindo a todo instante novas curiosidades a serem satisfeitas, estavam tomando gosto por aquelas leituras e aqueles estudos como nunca antes teriam imaginado; por outro, não viam a hora de voltar para junto das pessoas, de retomar contato com a vida, que agora lhes parecia muito mais complexa, quase renovada aos olhos deles; e, além disso, a aproximação do dia em que deveriam deixar a biblioteca enchia-os de apreensão, pois teriam que prestar contas de sua missão, e, com todas as idéias que andavam brotando em suas cabeças, não sabiam mais como sair dessa enrascada (CALVINO, 2001, p. 78).

Foi, então, que, quando a neve se pôs a derreter e os primeiros brotos dos galhos começaram a germinar, o general e sua comitiva abandonaram a biblioteca e seguiram em direção à base do comando supremo da Panduria, com o intuito de exporem os resultados de suas investigações. Alçando sua voz diante de um Estado-maior estupefato, Fedina proferiu um discurso que, aos moldes de um compêndio de história da humanidade, criticava com argumentos irrefutáveis as ideias então vigentes naquele país, denunciando as classes dirigentes como 
responsáveis pelas desventuras de sua pátria e exaltando o povo como vítima heróica de guerras e políticas equivocadas.

Era uma exposição um pouco confusa, com afirmações muitas vezes simplistas e contraditórias, como costuma acontecer com quem abraçou há pouco novas idéias. Mas sobre o significado geral não podia haver dúvidas. A assembléia dos generais da Panduria empalideceu, arregalou os olhos, reencontrou a voz, gritou. O general nem pôde terminar. Falou-se de degradação, de processo. Depois, temendo-se escândalos mais graves, o general e os quatro tenentes foram mandados para a reserva por motivos de saúde, por causa de "um grave esgotamento nervoso contraído no serviço" (CALVINO, 2001, p. 79).

Embora circunscritas ao âmbito da ficção, as figurações criadas por este amante dos livros e das bibliotecas, nos impulsiona a esboçar alguns questionamentos: o quê, de tão extraordinário, aconteceu, dentro daquela antiga biblioteca, que provocou uma mudança completa nos planos do general Fedina e do Estado-maior da Panduria? Estaria tal mudança ligada aos livros, à leitura e à biblioteca?

Como é sabido, a falta de relatos mais precisos, nos impede de forjar respostas concretas para a primeira questão, no entanto, naquilo que concerne à segunda, podemos tentar conjecturar algumas respostas, lançando mão de outras indagações: o que é a leitura e a quem podemos chamar de leitor? A biblioteca é, de fato, um espaço capaz de ampliar os recursos que dispomos para compreender e interpelar o mundo e a realidade que nos cerca? Em caso positivo, em que medida a conjunção entre as práticas de leitura e o universo das bibliotecas nos auxilia a projetar novos sentidos para nossas vidas?

Sem ostentar a pretensão de oferecer respostas definitivas para todas estas questões, o presente texto promove algumas considerações acerca das mesmas, com o intuito de defender que, enquanto instrumento privilegiado do saber, as bibliotecas (independentes se especializadas, públicas ou escolares) se portam como pouso seguro para todos os delírios, sonhos, paixões, aventuras e desventuras da alma humana. Salienta-se, ainda, que a leitura, enquanto prática concebida simbólica e socialmente, se exibe tal qual um espelho da experiência humana, definindo-a e dando-Ihe uma forma. Comecemos, pois, a refletir sobre nossa primeira questão: o que é a leitura e a quem podemos chamar de leitor?

\section{Caçar, viajar, imaginar: a leitura como prática cultural e o leitor como produtor de sentido}

Para um leitor, esta pode ser a razão essencial, talvez a única justificativa para a literatura: que a loucura do mundo não nos tome por completo, mesmo que invada nosso porão e depois, lentamente vá tomando nossa copa, a sala e a casa inteira. [...] Quando o mundo se torna incompreensível, quando atos de terror e respostas aterrorizantes para tal terror enchem nossos dias e nossas noites, quando nos sentimos desorientados e desconcertados, procuramos 
um lugar no qual a compreensão (ou a fé na compreensão) tenha sido expressa em palavras (MANGUEL, 2009, p. 59).

Embora muitos a visualizem como um elemento essencial para que o homem construa e edifique as relações que estabelece com o meio no qual se insere, a leitura não se configura como um ato natural, mas, antes, como um conjunto de fazeres históricos, sociais e culturalmente demarcados. É uma arte investigativa, que "quase não deixa traços visíveis nem garantias contra a usura do tempo, mas ação produtora que, em cada um dos seus encaminhamentos e de fazeres, ao mesmo tempo alteram e conferem existência ao texto". (CHARTIER; HÉBRARD, 1998, p. 32). É um jogo em torno da apropriação, da recriação. Ofício que não se restringe a um único conceito, mas, sim, a um universo de práticas difusas e em permanente transformação, através das quais sujeitos comuns interpretam e conferem os mais variados matizes de significação para o mundo que os cercam.

Razão pela qual não deve ser pensada como algo neutro em relação ao mundo, mas, sim, como ato que produz, na sua própria dinâmica, caminhos diferenciados para uma ação social concreta, em virtude da diversidade das necessidades e dos interesses de cada agente que the confere um sentido e um valor. Desta feita, e extrapolando uma acepção de cunho meramente denotativo, é possível se apontar que "a leitura não é apenas uma prática, mas uma forma de vida" (PIGLIA, 2006, p. 21). Em outros termos: mais que um ato hermenêutico ou uma exegese erudita, a leitura se converte em trabalho do pensamento, em recurso de apropriação do mundo, em movimento de ressignificação da realidade.

De fato, enquanto atividade interpretativa e de produção de sentido, a leitura não se posta como um processo de recepção delimitado por conteúdos objetivos ou como ato passivo de sujeição ao texto. Todo leitor, como nos aponta Michel de Certeau (1994), caça em terras alheias, "demarca com os olhos, com o dedo, com o franzir das sobrancelhas, com o sorriso, seus caminhos em busca do sentido. Sob a contingência, sem dúvida, e no espaço próprio do texto, ele elabora - como quer ou como pode - sua leitura do texto: um novo texto" (CHARTIER; HÉBRARD, 1998, p.33). Toda leitura é, então, um processo voluntário da inteligência, por meio do qual produzimos e sobrecodificamos sentidos e significados.

No entanto, mesmo ligando-se à inteligência, a leitura não se define como uma operação intelectual abstrata: ela é, também, o uso do corpo, uma inscrição dentro de um espaço histórico-temporal e uma relação dos leitores consigo mesmo e com os outros. Não por acaso, "ler tem a ver com a liberdade de ir e vir, com a possibilidade de entrar à vontade em um outro mundo e dele sair" (PETIT, 2009, p. 92). A leitura de qualquer texto é, portanto, um processo de construção cultural e histórica, que se efetiva a partir da mescla entre as condições materiais destinadas à sua produção e circulação, com a subjetividade e o lugar em que cada leitor se encontra no momento de executá-la. Em outras palavras: 
A atividade leitora apresenta, ao contrário, todos os traços de uma produção silenciosa: flutuação através da página, metamorfose do texto pelo olho que viaja, improvisação e expectação de significados induzidos de certas palavras, intersecções de espaços escritos, dança efêmera. [...] Ele [o leitor] insinua as astúcias do prazer e de uma reaproximação no texto do outro, aí vai à caça, ali é transportado, ali se faz plural como os ruídos do corpo. Astúcia, metáfora, combinatória, esta produção é igualmente uma "invenção" da memória. Faz das palavras as soluções de histórias mudas. A fina película do escrito se torna um remover de camadas, um jogo de espaços. Um mundo diferente (o do leitor) se introduz no lugar do autor (CERTEAU, 1994, p. 49, v. 1).

Neste sentido, as pistas lançadas pelo historiador acima citado, nos indicam que nenhum leitor é confrontado com textos abstratos, ideais ou desvinculados de uma materialidade espaço-temporal. Ao contrário, eles manipulam objetos, ouvem palavras cujas modalidades governam a leitura e a escrita. Fazendo isso, comandam os possíveis movimentos de compreensão e de apropriação do texto, da mesma forma como ressaltam que "toda história das práticas de leitura é, portanto, necessariamente uma história dos objetos escritos e das palavras leitoras". (CAVALLO; CHARTIER, 2002, p. 6). Deixam transparecer, em última instância, que a leitura constrói um espaço entre o imaginário e o real, e que este desmonta a clássica oposição binária entre ilusão e realidade, entre história e ficção. Indícios que corroboram para a tese de que não existe nada simultaneamente mais real e mais ilusório do que o ato de ler.

Sendo assim, lemos, mesmo se ler não é indispensável para viver, porque a vida é mais cômoda, mais clara, mais ampla para aqueles que leem que para aqueles que não leem. Por quê?

Primeiramente, em um sentido bastante simples, viver é mais fácil para aqueles que sabem ler, não somente as informações, os manuais de instrução, as receitas médicas, os jornais e as cédulas de voto, mas também a literatura. Além disso, supôsse por muito tempo que a cultura literária tornasse o homem melhor e lhe desse uma vida melhor: com a literatura, o concreto se substitui ao abstrato e o exemplo à experiência para inspirar as máximas gerais ou, ao menos, uma conduta em conformidade com tais máximas. A literatura, instrumento de justiça e de tolerância, e a leitura, experiência de autonomia, contribuem para a liberdade e para a responsabilidade do indivíduo (COMPAGNON, 2009, p. 29-35).

O leitor é, pois, um sujeito autônomo, capaz de construir sentidos e imprimir marcas interpretativas no texto que sobrecodifica. De dissecar o signo e de distender seus limites de compreensão. De subverter o texto, de torná-lo móvel, intercambiável. Sendo mais explícito: 
Longe de serem escritores, fundadores de um lugar próprio, herdeiros dos servos de antigamente, mas agora trabalhando no solo da linguagem, cavadores de poços e construtores de casas, os leitores são viajantes; circulam em terras alheias, nômades caçando por conta própria através dos campos que não escreveram. A escritura acumula, estoca, resiste ao tempo pelo estabelecimento de um lugar e multiplica sua produção pelo expansionismo da reprodução. A leitura não tem garantias contra o desgaste do tempo (a gente se esquece e esquece), ela não conserva, ou conserva mal a sua posse, e cada um dos lugares por onde ela passa é repetição do paraíso perdido. [...] Com efeito, a leitura não tem lugar (CERTEAU, 1994 , p. $269-270$, v.1).

Assim sendo, todo leitor revela-se como uma figura histórica, que respeita a historicidade do signo que lê, mas que, ao mesmo tempo, promove uma ruptura com as leituras feitas até então empreendendo sua própria interpretação, imprimindo sua marca pessoal no universo de possibilidades de significação que the é apresentado. O leitor é um viajante que desvenda ao longo do processo de leitura os sentidos, os significados, as múltiplas variantes interpretativas que a obra lhe oferece. Neste caso, nenhum texto se apresenta por completo, mas se evidencia durante a travessia, durante as intervenções de seus inúmeros leitores. Eis, então, o grande paradoxo da leitura:

Admite-se comumente que ler é decodificar: letras, palavras, sentidos e estruturas, e isso é incontestável; mas acumulando as decodificações, já que a leitura é, de direito infinita, tirando a trava do sentido, pondo a leitura em roda livre (o que é sua vocação estrutural), o leitor é tomado por uma intervenção dialética: finalmente ele não decodifica, ele sobrecodifica; não decifra, produz, amontoa linguagens, deixa-se infinita e incansavelmente atravessar por elas: ele é essa travessia (BARTHES, 1998, p.51).

Nestes termos, ele dispõe do poder de desvelar uma verdade que não seja transparente, mas latente, potencialmente presente, escondida fora da consciência, imanente, singular e, até aí, inexprimível. Ler é, pois, experimentar possíveis.

Experimentar possíveis, talvez tenha sido isso que o general Fedina e seus comandados descobriram ao longo daquele surpreendente inverno. Para, além disso, podem ter percebido que a leitura é, em si mesma, uma atividade que, através da experiência dos outros, se converte em "tentativa de agarrar o que está perdido, faltando, inacabado, de superar espaços, abolir fronteiras, reunir o que está separado, reconstituir terras desaparecidas, épocas passadas" (PETIT, 2009, p. 264-265).

Mas, por meio de quais artifícios o leitor - seja ele o general de nossa história ou aquele com o qual nos deparamos em nosso dia a dia se torna capaz de exercitar este universo de possibilidades que a leitura 
oferece? Ao vivenciar o texto e dele tomar posse, o leitor, por meio do confronto com outro, acaba por elaborar partes escondidas de si mesmo. Ao acessar o longínquo, depara-se com uma miríade de imagens, situações e personagens que fomentam seus pensamentos e cativam seus sonhos. Ao tomar conhecimento de culturas distintas, o leitor vê seu mundo e seu universo interior dilatar-se, ao mesmo tempo em que estrutura as bases nas quais sua individualidade se nutre, desenvolve-se e se valoriza. Dito de outra maneira, o que a leitura oferece àqueles que dela tomam parte:

São bens culturais que abrem de modo radical o tempo e o espaço e permitem, precisamente, um desvio. Desvio vital, que conduz a vias desconhecidas, em ruptura com a situação de cada um, recoloca em movimento o desejo, permite recarregar o coração, reencontrar, sob as palavras, emoções secretas compartilhadas, um pano de fundo de sensações, um laço com a infância; e que torna a movimentar o pensamento. É, então, um esquecimento temporário da dor, do medo ou da humilhação que se torna possível. Quase uma conjuração. Um local de acolhida é igualmente encontrado: os livros lidos são moradas emprestadas onde é possível se sentir protegido e sonhar com outros futuros, elaborar uma distância, mudar de ponto de vista. Para além do caráter envolvente, protetor, habitável, da leitura, uma transformação das emoções e dos sentimentos, uma elaboração simbólica da experiência vivida tornam-se, em certas condições, possíveis. (PETIT, 2009, p. 283-284).

É, por isso, que projetar explicações para as práticas de leitura exige compreendê-las como construtos sócio-culturais que só adquirem sentidos a partir da urdidura de inúmeras variáveis que, em nenhum momento, se isolam, encerrando em si, modos, ritmos, intensidades e desejos que variam de texto para texto e de leitor para leitor, da mesma forma que devemos tentar apreender as maneiras como estas se efetivam, nos vários lugares onde se desenvolvem. Espaços que podem ser a família, a igreja, os sindicatos ou diversas outras esferas da sociedade civil como as bibliotecas. É o que veremos a seguir.

\section{De palácios antigos a labirintos imaginários: pensando a biblioteca como espaço de leitura}

Pensei num labirinto de labirintos, num sinuoso labirinto crescente que abarcasse o passado e o futuro e que envolvesse, de algum modo, os astros. Absorto nessas ilusórias imagens, esqueci meu destino de perseguido. Senti-me, por tempo indeterminado, com percepção abstrata do mundo [...].

Aqui está o labirinto. Um labirinto mínimo... Um labirinto de símbolos... Um invisível labirinto de tempo (BORGES, 1998, p. 528-529).

Ao lançar seu olhar sobre a história da leitura, um observador atento percebe de imediato que a biblioteca se configura, de fato, como 
lócus privilegiado para que a alquimia da leitura se desenvolva e se efetive. Isto porque, por entre seus corredores e estantes que preservam a infinitude do conhecimento humano, cada usuário se sente confortável para buscar, encontrar e utilizar determinada informação, convertendo-a, posteriormente, em insumo gerador de novos conhecimentos. Neste sentido:

Uma visita demorada às bibliotecas nos permite viver e reviver a singular experiência que ocorre quando estabelecemos um diálogo com os sábios que nos antecederam. É sempre provocador de demoradas reflexões. E por serem portadores de sabedoria não deixam de nos instruir ainda quando suas vozes se encontram silenciadas. Se não falam aos nossos ouvidos, estabelecem com os leitores uma conversa no plano do entendimento. E despertam nossa curiosidade, ativando a mente para perscrutar, por eles e com eles, os obscuros caminhos por onde trilharam as diversas experiências da humanidade (RODRIGUES, 1999, p. 82).

Ler e estudar em uma biblioteca é, segundo esta perspectiva, tentar promover a atividade dialética que se instaura entre a totalidade e suas partes, entre a promessa de uma memória universal, mas que ultrapassa o olhar de todo indivíduo e os itinerários pacientes, parciais e atípicos desenvolvidos por cada sujeito em processo de interação com as várias materialidades físicas e simbólicas que constituem os acervos destas instituições. Razão pela qual, no cerne de uma biblioteca, a atividade dos leitores também não se delimita a tarefa de reunir informações, ordenálas e catalogá-las. Mais que isso, eles devem potencializar suas leituras apossando-se dos acervos, promovendo associações impensadas, dialogando com vozes aparentemente silenciadas. Ler e estudar em uma biblioteca é, ainda, de acordo com esta proposição:

Tentar conciliar um desejo de universalidade e a necessidade de escolha, de seleção, até mesmo de esquecimento, como as próprias condições da leitura e do pensamento. O trabalho na biblioteca é percurso no interior de um livro, em seguida de livros para livros e dos livros para o mundo, com suas travessias áridas, suas erranças labirínticas e seus momentos de jubilação intelectual, suas caminhadas míopes e seus grandes panoramas. É também uma viagem no tempo, uma "anábasis" nas ramificações da memória do saber e da criação de um espaço de encontros utópicos e ucrônicos convergência das idéias, perenidade e metamorfoses dos modelos e das lições, afinidades eletivas ou escolhas longamente refletidas, em que se reaviva o pensamento e o saber de outrem e de outrora através do comentário, da leitura e do jogo livre das digressões (JACOB, 2000, p. 10). 
Relação instituída há longa data, uma vez que a história da leitura é indissociável da história das bibliotecas, estando suas dimensões sócioculturais atreladas às formas e circunstâncias, por meio das quais cada um destes elementos se exibem no tempo e nos espaços onde se concretizam. Sendo assim, o que torna uma biblioteca o reflexo de seus leitores não é tão somente o movimento de seleção dos títulos que estes poderão vir a ler, mas a urdidura das associações implícitas que este gesto deixa transparecer. Neste sentido, se é verdade que a leitura nos permite recordar a experiência comum a toda humanidade, as bibliotecas nos auxiliam a perceber o mundo de dois ângulos distintos: como terra estrangeira ou como lar. Em outras palavras:

Vagando entre nossos livros, tirando um volume da estante e folheando-o ao acaso, as páginas ou bem nos espantarão por diferir de nossa experiência ou bem nos confortarão por sua semelhança. A cabeça de Agamêmnon ou a brandura do lama de Kim me são absolutamente estranhos; a surpresa de Alice ou a curiosidade de Sinbad refletem uma e outra vez minhas próprias emoções. Todo leitor é um andarilho ou um viajante de retorno. (MANGUEL, 2006, p. 253).

Razão pela qual as bibliotecas se convertem em centramento do saber, vontade de poder, reserva como fundo, tesouro. "Biblioteca, que a letra já aponta para o sentido de sua história - gr. biblion + thêkê - cofre, lugar de depósito. A biblioteca de Alexandria, a biblioteca de Babel. Lugar de tesouros, lugar de muitas línguas, castigo de Deus-Pai" (CASA-NOVA, 1990, p. 132).

Em associação com a leitura, as bibliotecas transmutam-se, também, em conservatórios de sentido, nos quais, segundo PETIT (2009, p. 125), encontramos metáforas científicas que nos auxiliam a ordenar o mundo e o esclarecer, metáforas literárias, poéticas, geradas pelo exercício lento de escritores ou de artistas que realizaram um trabalho de transfiguração de seus próprios questionamentos e dos vários conflitos que estão no cerne da vida psicológica e social. Ao fazer isso, a conjunção entre leitura e biblioteca outorga uma espécie de sentido para a vida de seus usuários. Sentido que abre para estes uma miríade de possibilidades: de transformação, de inspiração, de acesso à tradição.

Possibilidades que nos leva a visualizar as bibliotecas como "lugares de tradição". Como espaços que conservam o conjunto dos valores dentro dos quais nos reconhecemos enquanto seres sociais, uma vez que estas instituições não preservam apenas a materialidade concebida para comportar os saberes ou as opiniões que temos, mas, e, sobretudo, a totalidade do conhecimento humano que só se deixa elucidar a partir do conjunto de valores constitutivos de uma dada sociedade.

Característica que Ihe confere, em um segundo plano, o status de "lugar de contradição", posto que, por trás da aparente calmaria de seus corredores e de suas estantes, toda biblioteca se apresenta como arena de acirradas disputas ideológicas, onde convivem, lado a lado, e em suposta harmonia, vozes de autores distintos e com idéias, em ampla 
medida, incongruentes e dissonantes, cuja validade se determina e se manifesta através da ansiedade de seus múltiplos leitores.

Portanto, seja como espaço físico, como símbolo de uma ordem cósmica ou social ou como forma visível da razão humana, as bibliotecas são lugares que guardam histórias e despertam o fascínio e o encantamento. Lugares onde tais elementos se transmutam, perturbando e excitando fantasias, irmanando o sonho com a ação, além de provocarem medo e instigarem reações.

Por isso, independentemente de sua "realidade", as bibliotecas oferecem a base de repertório em que nossa imaginação opera. Contém, internamente, um tratamento crítico realizado pelo responsável por sua constituição. Nem por isso deixam de denunciar a existência de outras possibilidades organizativas ou seletivas. Compreender essa crítica prévia e perceber seus vínculos com o tempo e com as leituras que então se davam permite sobrepor a ela outro exercício crítico e, nesse cruzamento, enxergar a historicidade da cultura, o diálogo entre temporalidades. Permite realizar balanços dos textos que fundam cada experiência histórica (PINTO, 2004, p. 42).

Para sermos mais precisos, por intermédio das bibliotecas, nos tornamos capazes de compreender que, em todos os momentos da história do Ocidente, o homem tentou achar respostas para o seguinte paradoxo: obcecados pelo sonho de uma instituição total que reunisse todos os textos da terra em um só lugar (e Alexandria é o grande ícone desta busca), sempre nos vimos atormentados pela realidade decepcionante das bibliotecas reais que, por maiores que sejam, somente podem fornecer uma imagem parcial, lacunar e mutilada do conhecimento universal. Talvez, por isso, através da conservação de livros que se multiplicam ao infinito, vemos "manifestar-se a angústia surda do tempo que passa e que destrói, o medo de perder-se nessa enchente de letras e palavras sempre ameaçadas pela ignorância, pela violência, pela história, pelo tempo e pela barbárie dos homens" (GOULEMOT, 2000, p. 261).

Paradoxo que não reduz a função social das bibliotecas, uma vez que - e a história dos livros nos serve de aporte para esta afirmação seja qual for o seu tamanho, um acervo não precisa ser lido por inteiro para se fazer útil. Isto porque, ao estabelecer seus próprios itinerários entre as salas, corredores e estantes de uma biblioteca, todo leitor acaba por tirar proveito de um sábio equilíbrio entre conhecimento e ignorância, entre lembrança e esquecimento. Portanto.

Se existe um lugar propício aos desvios e aos encontros inesperados, é a biblioteca. [...] Ali, podemos experimentar uma relação com o livro que não se funda somente nas perspectivas utilitaristas da instrução, e nos abandonar a esses tempos de devaneio em que não se deve prestar contas a ninguém, nos quais se forja o sujeito e que, tanto quanto os 
aprendizados, ajudam a crescer e a viver (PETIT, 2009, p. 273).

Talvez tenha sido isso que o bibliotecário Crispino sorrateiramente ensinou às tropas do general Fedina. Personagem discreto, mas que se move com habilidade pelas galerias quase congeladas da velha biblioteca panduriana. Homem sábio, que não se assusta com os movimentos e com os intentos militares. Leitor generoso, que oferece um alento às dúvidas e aos anseios daqueles que só tardiamente travaram contato com o mundo dos livros. Profissional exemplar, que, como um ofício de fé, certamente estava convencido de que, caso suas ações não surtissem efeito e tudo ali perecesse, em algum outro lugar:

É provável que as bibliotecas persistam e sobrevivam, na medida em que continuemos a emprestar palavras ao mundo que nos cerca e a preservá-las para leitores futuros. Tanta coisa foi nomeada, tanta coisa ainda será nomeada, que nem mesmo nossa estupidez poderá fazer que abandonemos esse pequeno milagre que nos garante uma ilusão de entendimento. Os livros podem não alterar nosso sofrimento, os livros podem não nos proteger do mal, os livros podem não nos dizer o que é o bom e o que é o belo, e certamente não terão como nos livrar do destino comum - a tumba. Pode bem ser que nenhum livro, por mais bem escrito que seja, consiga remover um grama de dor da tragédia do Iraque ou de Ruanda, mas pode bem ser que não haja livro, por mais mal escrito que seja, que não contenha alguma epifania para algum leitor (MANGUEL, 2006, p. 192-193).

Desta forma, embora se constate que o imaginário que define os signos informacionais, como ícones revestidos de poder seja uma concepção característica das sociedades arcaicas, vemos que a mesma se prolonga até os dias atuais, sendo as bibliotecas uma das principais esferas responsáveis por sua constante revitalização. Isto porque, enquanto lugares de práticas culturais e enquanto espaço de leitura, as bibliotecas e seus acervos adquirem a capacidade de interferir nos cenários sócio-políticos em que se inserem, fazendo frutificar o saber acumulado e contribuindo para a preservação e difusão de todo o legado cultural humano.

Neste sentido, e como síntese daquilo que se expôs até aqui, podemos caracterizar as bibliotecas como lugares de continuidade, estando seu poder diretamente ligado à função de preservar, organizar e transmitir a materialidade que define os saberes e a cultura humana. Em razão disso, sua história se converte na história daquilo que uma sociedade decide transmitir, nos conhecimentos que decide conservar, na necessidade de seu esquecimento para posterior recuperação, mas, sobretudo, na reevocação e reutilização destes, a partir dos múltiplos 
gestos associados às práticas de leitura. Cremos serem estes os ensinamentos que o general Fedina e sua tropa desvelaram naqueles dias frios de inverno panduriano. Discorremos um pouco mais sobre isso nas páginas que se seguem.

\title{
4 Considerações finais
}

\author{
Lutar com palavras é a luta mais vã. \\ Entanto lutamos mal rompe a manhã [...]. \\ Não me julgo louco. Se o fosse, teria poder de encantá-las. Mas lúcido e frio, apareço e tento \\ apanhar algumas para meu sustento num dia de vida (ANDRADE, 2002).
}

Talvez, a lição mais importante que Roland Barthes tenha nos legado, em sua "Aula" inaugural para a cadeira de Semiologia Literária do Collége de France, em 1977, seja aquela que destitui o texto literário de seu caráter meramente descritivo. Para o referido autor, o signo linguístico não se encontra preso a um conteúdo apenas, visto ser capaz de, e esta é condição própria de sua existência, dialogar com os vários vértices (o cultural, o social, o político, entre outros), que possibilitam ao leitor mobilizar a gama de impressões, sentimentos e conhecimentos necessários para interpretar o mundo que o cerca e, ao mesmo tempo, tornar-se verdadeiramente membro deste.

Sendo assim, ao assinalar que o discurso literário não se detém na estagnação e na fixidez inerente a todo discurso científico, Roland Barthes defende que a literatura realiza, por meio da escritura, a façanha de conceber redes variadas de saberes e transformar conceitos estanques em fronteiras móveis que se potencializam e adquirem sentido pelo aspecto múltiplo da palavra. Para tanto, no lugar existiria um único ponto de vista, a literatura faz emergir inúmeros outros ângulos de compreensão. Ao contrário do discurso científico, que tem compromisso com as regras e com as normas, a linguagem literária trabalha, vorazmente, incluindo a diversidade e a multiplicidade em sua criação. Nas palavras do próprio autor:

[...] a literatura faz girar os saberes, não fixa, não fetichiza nenhum deles, ela Ihes dá um lugar indireto, e esse indireto é precioso. Por um lado, ele permite designar saberes possíveis - insuspeitos, irrealizados: a literatura trabalha nos interstícios da ciência: está sempre atrasada ou adiantada em relação a esta. A ciência é grosseira, a vida é sutil, e é para corrigir esta distância que a literatura nos importa. Por outro lado, o saber que ela mobiliza nunca é inteiro nem derradeiro; a literatura não diz que sabe alguma coisa, mas que sabe de alguma coisa; ou melhor: que ela sabe algo das coisas - que sabe muito sobre os homens (BARTHES, 2004, p. 18-19). 
Formulação que traz sobrescrito, em seu cerne, o seguinte paradigma: ao inverso da rigidez conceitual da ciência, o saber literário, através do confronto entre leitor e texto, amplia a compreensão das coisas que nos cercam e nos ajuda a lidar com nossa própria e intransferível morte, na medida em que trabalha ludicamente com a noção de duplicidade que está presente na condição humana. A duplicidade resultante da alteridade intrínseca dos seres humanos. Em outras palavras, através da interpretação do texto literário e da linguagem dos poetas e contadores de histórias, adquirimos a capacidade de buscar o conhecimento indireto que encena o sentido do fim que nos atravessa e de reconhecer algo que não sabíamos que conhecíamos. No entanto, para que tal estatuto se faça perceptível:

A literatura tem de voltar-se para aqueles homens [homens e mulheres protagonistas ativos da história], tem de ensinarIhes enquanto deles aprende, servir-Ihes, e pode servir apenas numa coisa: ajudando-os a ser cada vez mais inteligentes, sensíveis, moralmente fortes. As coisas que a literatura pode buscar e ensinar são poucas, mas insubstituíveis: a maneira de olhar o próximo e a si próprios, de relacionar fatos pessoais e fatos gerais, de atribuir valor a pequenas coisas ou a grandes, de considerar os próprios limites e os vícios e os dos outros, de encontrar as proposições da vida e o lugar do amor nela, e sua força e seu ritmo, e o lugar da morte, o modo de pensar ou de não pensar nela; a literatura pode ensinar a dureza, a piedade, a tristeza, a ironia, o humor e muitas outras coisas assim necessárias e difíceis. O resto, que se vá aprender em algum outro lugar, da ciência, da história, da vida, como nós todos temos de ir aprender continuamente (CALVINO, 2006, p. 21).

Em suma, são as vozes dos discursos literários que dão ao mundo sua aparência de narratividade, que concentram e dramatizam a matériaprima da experiência, que traduzem a tristeza e o encantamento em prazeres estéticos. Razão pela qual a literatura se apresenta como instância indispensável para a compreensão, pelo homem, de suas circunstâncias de vida e de sua própria história. Portanto, embora não almeje alcançar a verdade, o discurso ficcional fornece elementos e fragmentos que permitem ao leitor reconstruir momentos reais que marcaram sua trajetória de vida ou de todo um período histórico.

Mesmo sem atentar para tais possibilidades, talvez tenham sido estes os movimentos que instigaram o exército do general Fedina a reivindicar um novo rumo para as vidas dos habitantes da Panduria. Ao travar contato com os livros daquela velha biblioteca, talvez os personagens de Ítalo Calvino tenham se dado conta de que as histórias e "estórias" neles preservadas não são uma ilusão. Ao contrário, elas deleitam e instruem. Sendo mais preciso: elas instruem deleitando. 
Podem ter descoberto, ainda, que os livros e sua leitura evocam experiências, falam dos outros e de cada um de nós em particular. $E$, para, além disso, arrisco-me a dizer que eles apreenderam o poder emancipador que as bibliotecas, os livros e a leitura trazem consigo. Poder este que nos conduzirá "por vezes a querer derrubar os ídolos e a mudar o mundo, mas quase sempre nos tornará simplesmente mais sensíveis e mais sábios, em uma palavra, melhores" (COMPAGNON, 2009, p. 51).

Portanto, embora se constitua em essência como um lugar de diálogo com o passado, toda biblioteca funciona, também, como espaço de criação e inovação, onde a conservação só tem sentido como fermento dos saberes a serviço da coletividade inteira. O que implica ressaltar que, se o conhecimento é acumulativo, as bibliotecas, através do exercício de coleta, organização, preservação e disseminação da informação, bem como do incentivo às práticas de leitura capitalizam essa herança e permitem aumentá-la graças a atividade daqueles que as exploram.

A biblioteca parece assim ser uma espécie de Penélope que tece os fios da teia do tempo e do conhecimento, e à noite a desfaz pelo silêncio, para recomeçar no outro dia o mesmo trabalho. Palavra efêmera, conhecimento efêmero. A teia, o tecido é esse grande discurso que ela encara no que é manifesto, e naquilo que se mostra, e no que é subterrâneo, latente; precisa e se quer desvelado (CASA NOVA, 1990, p. 136).

A biblioteca não é mais, por conseqüência, um mero depósito de livros: esse o mais importante de todos os pontos característicos na evolução de seu conceito. À sua passividade, substituiu-se um salutar dinamismo, a iniciativa de uma obra que é, ao mesmo tempo, de socialização, especialização, democratização e laicização da cultura. Ela desempenha, dessa forma, e por menos que pareça, um papel essencial na vida das comunidades modernas; é, em torno dela, que circulam todas as outras correntes da existência social. Função agregadora que, por meio das várias formas de sociabilidade que os livros e a leitura engendram, convertem as bibliotecas em espaços de experiências coletivas. Assertiva também atestada por Ítalo Calvino, na última de suas Seis propostas para o próximo milênio, na qual encontramos o seguinte apontamento:

Quem somos nós, quem é cada um de nós senão uma combinatória de experiências, de informações, de leituras, de imaginações? Cada vida é uma enciclopédia, uma biblioteca, um inventário de objetos, uma amostragem de estilos, onde tudo pode ser continuamente remexido e reordenado de todas as maneiras possíveis (CALVINO, 2008, p. 138).

Reordenar a vida, expandir suas dimensões e encontrar um sem número de respostas possíveis para os seus mais distintos paradoxos, eis, talvez, os principais benefícios que as bibliotecas e a leitura nos oferecem. 
Eis, também, as principais razões pelas quais lhes rendemos um elogio. Elogio que, em ampla medida, pode ser visualizado como a matéria-prima do discurso que o general Fedina e seus comandados proferiram no parlamento do Estado-maior da Panduria. Discurso emancipador, por vezes incerto, mas que, se inquirido com a atenção que merece, portarse-á como modelo de resposta até mesmo para as questões que motivaram este texto. Questões complexas e seguramente portadoras de múltiplas respostas.

Sendo assim, e sem desconsiderar qualquer outra possibilidade de enunciação, o percurso aqui traçado acena para uma de suas mais simples formulações: um livro e até mesmo uma biblioteca inteira não é capaz de fazer mais do que iluminar o caminho que seu leitor escolheu. Claridade difusa, tênue por essência, mas imbuída de uma habilidade ímpar: apontar para trilhas que outros percorreram, para esperanças que outros projetaram e que talvez possam nos servir de alento em um dia de desespero ou de inspiração para tardes de descontraídas leituras. Não por acaso, foi no cerne de uma biblioteca que o general Fedina se tornou um leitor e se deixou seduzir pela força das palavras, a partir da qual se mostrou convencido de que tudo aquilo que podemos imaginar sempre existe, em outra escala, em outro tempo, nítido e distante, como em um sonho. Sonho tantas vezes embalado por histórias inscritas nas páginas de um livro que encontramos esquecido na estante de uma biblioteca qualquer.

\section{Referências}

ANDRADE, C. D. de. O lutador. In: ANDRADE, C. D. de. José. Rio de Janeiro: Nova Aguilar, 2002. p. 99-101. (Poesia completa).

BAKHTIN, M. Questões de literatura e estética: a teoria do romance. $4^{a}$ ed. São Paulo: UNESP/HUCITEC. 1998 (Linguagem e cultura; 18).

BARTHES, R. Aula. 12 ed. São Paulo: Cultrix, 2004.

BARTHES, R. O rumor da língua. São Paulo: Brasiliense, 1998.

BARTHES, R.; COMPGNON,. Leitura. In: Enciclopédia Einaudi. Porto: Imprensa Nacional/Casa da Moeda, 1987. p.184-206, v. 11 (Oral / Escrito / Argumentação).

BORGES, J. L. O jardim de veredas que se bifurcam. In: BORGES, J. L. Ficções. São Paulo: Globo, 1998. p. 524-533. (Obras completas, 1).

CALVINO, Í. O general na biblioteca. In: CALVINO, Í. O general na biblioteca. 2. ed. São Paulo: Companhia das Letras, 2001. p. 74-79.

CALVINO, Í. Assunto encerrado: discursos sobre literatura e sociedade. São Paulo: Companhia das Letras, 2006.

CALVINO, Í. Seis propostas para o próximo milênio. 3. ed. 6. reimp. São Paulo: Companhia das Letras, 2008. 
CANDIDO, A. Literatura e sociedade. 8. ed. São Paulo: Publifolha, 2000. (Grandes nomes do pensamento brasileiro).

CASA-NOVA, V. Biblioteca: uma leitura semiológica. R. Esc. Bibliotecon. UFMG, B. Hte., v. 19, n. esp., p. 130-137, mar. 1990.

CAVAlLO, G.; CHARTIER, R. História da leitura no mundo ocidental. São Paulo: Ática, 2002. 2 v.

CERTEAU, M. de. A invenção do cotidiano. Petrópolis: Vozes, 1994. 2 v.

CHARTIER, A.-M.; HÉBRARD, J. A invenção do cotidiano: uma leitura, usos. Proj. História, São Paulo, v. 17, p. 29-44, nov. 1998.

CHARTIER, R. (Org.). Práticas da leitura. São Paulo: Estação Liberdade, 1996.

CHARTIER, R. Textos, impressão, leituras. In: HUNT, Lynn. A nova história cultural. 2. ed. São Paulo: Martins Fontes, 2001, p.211-238. (O homem e a história).

CHARTIER, R. Une histoire de la culture écrite: culture écrite et littérature à l'âge moderne. Annales HSS, jui./oct. 2001, n.4-5, p.783-802.

COMPAGNON, A. Literatura para quê? Belo Horizonte: Ed. UFMG, 2009.

FREIRE, P. A importância do ato de ler: em três artigos que se completam. 29. ed. São Paulo: Cortez, 1994. (Questões da Nossa Época, 13).

GINZBURG, C. Mitos, emblemas, sinais: morfologia e história. São Paulo: Companhia das Letras, 1989.

GOULEMOT, J.-M. Bibliotecas, enciclopedismo e angústias da perda: a exaustividade ambígua das Luzes. In: BARATIN, M.; JACOB, C. (Orgs.). $O$ poder das bibliotecas: a memória dos livros no ocidente. Rio de Janeiro: UFRJ, 2000. p.257-270.

ISER, W. O ato da leitura: uma teoria do efeito estético. São Paulo: 34, 1996. $2 \mathrm{v}$.

JACOB, C. Ler para escrever: navegações alexandrinas. In: BARATIN, M.; JACOB, C. (Orgs.). O poder das bibliotecas: a memória dos livros no ocidente. Rio de Janeiro: UFRJ, 2000. p. 45-73.

JACOB, C. Prefácio. In: BARATIN, M.; JACOB, C. (Orgs.). O poder das bibliotecas: a memória dos livros no ocidente. Rio de Janeiro: UFRJ, 2000. p. 9-17.

MANGUEL, A. A biblioteca à noite. São Paulo: Companhia das Letras, 2006.

MANGUEL, A. A cidade das palavras: as histórias que contamos para saber quem somos. São Paulo: Companhia das Letras, 2008.

MANGUEL, A. À mesa com o Chapeleiro Maluco: ensaios sobre corvos e escrivaninhas. São Paulo: Companhia das Letras, 2009. 
MANGUEL, A. Uma história da leitura. São Paulo: Companhia das Letras, 1997.

MÜLLER, S. P. M. Biblioteca e sociedade: evolução da interpretação das funções e papéis da biblioteca. R. Esc. Bibliotecon. UFMG. Belo Horizonte, v. 13, n. 1, p. 7-54, mar. 1984.

PERROTTI, E. O leitor na cultura: a formação da leitura infantil e juvenil. 1989. 165 f. Tese (Doutorado em Comunicação) - Escola de Comunicação e Artes, Universidade de São Paulo; São Paulo, 1989.

PETIT, M. A arte de ler: ou como resistir à adversidade. São Paulo: Ed. 34, 2009.

PIGLIA, R. O último leitor. São Paulo: Companhia das Letras, 2006.

PINTO, J. P. A leitura e seus lugares. São Paulo: Estação Liberdade, 2004.

RODRIGUES, N. Elogio à educação. São Paulo: Cortez; 1999.

SERRAI, A. História da biblioteca como evolução de uma idéia e de um sistema. R. Esc. Bibliotecon. UFMG, Belo Horizonte, v. 4, n. 2, p. 141-161, set. 1975.

SILVEIRA, Fabrício José Nascimento da. Biblioteca como lugar de práticas culturais: uma discussão a partir dos currículos de Biblioteconomia no Brasil. 2007. 246 f. Dissertação (Mestrado em Ciência da Informação) Escola de Ciência da Informação da Universidade Federal de Minas Gerais, Belo Horizonte, 2007.

STEINER, G. Nenhuma paixão desperdiçada: ensaios. Rio de Janeiro: Record, 2001.

YUNES, E. Leitura, a complexidade do simples: do mundo à letra e de volta ao mundo. INFORMARE: Cad. Prog. Pós-Grad. Ci. Inf., Rio de Janeiro, v. 5, n. 1, p. 6-29, jan./jun. 1999.

${ }^{\mathrm{i}}$ Este artigo constitui-se como versão ampliada de um trabalho apresentado à disciplina Fundamentos da leitura e formação do leitor, do PPGCI/UFMG, ministrada pela Profa. Dra. Maria da Conceição Carvalho, a quem agradeço o incentivo e as considerações. 